\title{
Towards a New Justificatory Theory of Comparative Constitutional Law
}

\author{
Santiago Legarre*
}

\begin{abstract}
This paper tries to explain what comparative constitutional law is and takes the US legal practice as an example. The presence of comparative analysis is considered both in the academic arena and in the case law of the US Supreme Court. The conclusion of this part of the article is that for comparative constitutional law to be valid its role ought to be restricted by several constraints. The article also suggests that the comparative enterprise only makes sense if the universality of human rights is first acknowledged. The paper next delves into such universality and connects it with notions of new classical natural law that are considered essential in order to adequately understand the problem. Finally, it provides an example of the misuse of comparative constitutionalism.
\end{abstract}

\section{Introduction}

As I awoke in my hotel room in Baton Rouge, Louisiana, on 15 January 2005, my eyes caught an unusual picture on the front page of the New York Times: United States of America (US) Supreme Court Justices Antonin Scalia and Stephen Breyer were portrayed sitting on armchairs in a living room, in what seemed to be - and was - a debate at American University in Washington DC. ${ }^{1}$

1 On the origins of the Scalia-Breyer debate, see Dorsen $\mathrm{N}$, 'The relevance of foreign materials in US constitutional cases: A conversation between Justice Antonin Scalia and Justice Stephen Breyer'

3 International Journal on Constitutional Law 4 (2005) 519, 519-520, which includes a lightly edited

* Professor of Law, Universidad Católica Argentina; Visiting Professor, University of Notre Dame Law School and Strathmore Law School (Nairobi); researcher, CONICET (Buenos Aires). LLB., Universidad Católica Argentina; MSt, Oxford; PhD., Universidad de Buenos Aires. I thank Zachary Calo, Rick Garnett, Claire Leatherwood, Richard Ekins, Seba Elias, Randy Kozel, Malenita Munoz Legarre, Florencia Ratti Mendaña, and Paul Yowell for their gracious comments. I have also benefited from helpful remarks by those present at the Notre Dame Law School Faculty Workshop of 27 March 2014. 
Given that the reason for my presence in the United States at that time was to teach a class titled "Comparative constitutional law" my eyes became even more dilated when I realised that the debate had been on the use of foreign law in constitutional adjudication.

Furthermore, I learned subsequently, that debate had been broadcast live on television by C-Span, the Cable-Satellite Public Affairs Network, a mainstream US cable television network. The Supreme Court justices had competed with the Simpsons. Though the fight was probably not a fair one the mere fact that you can even watch Supreme Justices discussing academic matters on TV is telling. These, however, were not just any academic matters. The fact that this happened instructs us about the pressing public relevance of the debate around comparative constitutional law. Or, if you want to put it critically, and to borrow from another Supreme Court justice, it instructs us about "moods, fads, or fashions."

In any case, and possible fashions apart, it is clear that the Scalia-Breyer debate is only an outstanding manifestation of a broader reality: the explosion in the last few decades of comparative constitutional law both as an academic discipline and as a judicial practice, especially of supreme courts and constitutional tribunals; and especially regarding fundamental human rights. ${ }^{3}$ This is true, at least, in the Western world; though recent teaching trips to East Africa and to India have alerted me to the reality that the span of the comparative constitutional wave is perhaps not thus confined. ${ }^{4}$

When it comes to what could be termed judicial comparative constitutional law, typically a national supreme court of country $A$ will invoke a decision of the national supreme court of country $B$ in order to justify a decision in country $A$ or in order to reinvigorate a certain reasoning or the reasonableness of a certain

transcription of the discussion, approved by the two Justices. References to the debate in this article, however, are from the literal transcript, that can be found in http://domino.american.edu/ AU/media/mediarel.nsf/1D265343BDC2189785256B810071F238/1F2F7DC4757FD01E85256F 890068E6E0?OpenDocument, on 10 January 2014. It ought not to be confused with a different one, between the same Justices and also held in Washington DC, but on different topics. The latter one, co-organised by the American Constitution Society and the Federalist Society can be consulted here: http://www.fed- soc.org/publications/pubID.173/pub_detail.asp\#, on 8 January 2014.

2 Foster v Florida, 537 US 990, n (2002) (Thomas J concurring in denial of certiorar).

3 Groppi T and Ponthoreau M, The use of foreign precedents by constitutional judges, Hart Publishing, Oxford 2013, 416 (explaining how their research shows that citations of foreign case law prevail "in human rights decisions, whereas they appear less frequently in institutional decisions".)

4 I presented an earlier version of this paper in Nairobi, Kenya, and in Bhubaneswar, Orissa, in the remote confines of India, and the ideas were received with warm interest by the local faculty present. A recent study seems to confirm my impression with regard to several common law and mixed jurisdictions, including India. Groppi and Ponthoreau, The use of foreign precedents, 412-415, 428. 
result in country $A$. All of which ought to be distinguished from a different, but related situation: where country $A$ is part of a regional human rights organisation governed by a human rights treaty, applied and enforced by a human rights court; in which case the supreme court of country $A$ is typically bound to abide by the case law of that regional human rights court - as it happens in the European countries with the judgments of the European Court of Human Rights, to give one example. ${ }^{5}$ While in this latter situation the supreme court of $A$ is in some sense legally bound by a case law that is in a way "foreign" (the case law of the European Court), with "judicial comparative constitutional law" the situation is significantly different, as the supreme court of $A$ will (sometimes) follow foreign law without being bound to do so at all. ${ }^{6}$

This article offers a basic theory of both judicial and academic comparative constitutional law and tries to provide a justification for it. ${ }^{7}$ To prepare the grounds for that theory Parts 1 and 2 focus on the US as an example for the following reasons. ${ }^{8}$ First, it is precisely in the US where comparative constitutional law has flourished most in the last few decades. This is unsurprising given that once something gets moving in that huge country reasons of scale and availability of resources make it likely that it will soon become the place in the world where that something will receive more attention - in our case comparative constitutional law, but one could argue that soccer will be next. Second, whether one likes it or not, the US constitutional system is the forerunner of many others and is, at the same time, a recurrent object of praise or criticism. Moreover, many of the important comparative constitutional questions have been brought to the limelight by the American controversy on comparative constitutional law; so by focusing on this debate one delves simultaneously, to some extent, into the

As it is well known, the extent to which it is true that the courts of the European countries are actually bound by the decisions of the Strasbourg court differs as a result of domestic norms and practices. See e.g., for the case of the UK, Section 2, Human Rights Act (2008).

6 As Neuman explains, these two situations are oftentimes confused, although they are quite different. Neuman GL, 'International law as a resource in constitutional interpretation' 30 Harvard Journal of Law and Public Policy (2006) 177, 177-180. Like Professor McCrudden "I am interested in the use of foreign human rights law, not international human rights law, nor foreign human rights law that purports to be interpretative of international human rights law (although clearly there is a close connection in some cases)." McCrudden C, 'A common law of human rights: Transnational judicial conversations on constitutional rights' 20 Oxford Journal of Legal Studies 499, (2000), 510.

Some time ago I offered a first version of this theory in an article written in Spanish together with my Chilean colleague Orrego C, 'Los usos del derecho constitucional comparado y la universalidad de los derechos humanos’ 88 Revista Española De Derecho Constitucional 11 (2010).

8 It is of course only an example, without prejudice to European contributions to the field, that are perhaps more traditional and better known, partly in connection to the phenomenon of the European Union and its predecessors. 
equivalent controversies and discussions in other jurisdictions. Third, given the aim of this piece - to query the justification of comparative constitutional law I find it advisable to concentrate in one jurisdiction rather than dispersing one's efforts across several. The Latin saying "non multa sed multum" that captures the essence of the distinction between the English words "many and much" commends this approach.

Part 3 offers a basic theory of the reasonable use of foreign materials in constitutional adjudication. While not fully original my theory is necessary in order to introduce the next, crucial section, where I seek the justification of comparative constitutionalism. Part 4 contends that the theory of comparative constitutional law only holds full meaning and sense if coupled with the acceptance of the universality of fundamental human rights. This contention finds its most prominent application in the area of rights adjudication. If, contrariwise, one denies the universality of fundamental human rights the comparative enterprise becomes unintelligible - which, as will be seen, is not akin to affirming that it becomes impossible as a matter of fact. At the same time it will be argued that moral relativism is incompatible with the above-mentioned universality and, also, that the latter is best explained by the acknowledgment that certain truths about the human person have an objectivity and evidence that cannot be proved. These truths have been traditionally captured by the name "natural law" and have been elaborated by the classical thinking that opposed moral relativism, and expanded in recent times by the new classical natural law theory. Finally, Part 5 provides a counter example by showing an instance of misuse of comparative constitutional analysis and by issuing a warning regarding the prevention of similar abuses.

\section{Academic Comparative Constitutional Law}

The debate related in the introduction is in itself culturally iconic. ${ }^{9}$ But in the US interest in foreign law - and in comparative law as a method of analysis and research-springs from the conclusion of the Second World War at the latest. A clear indication of that interest is the sponsorship that the Association of American Law Schools (AALS) - a non-profit organisation gathering most law schools in the US - awarded in 1948 to the meeting of the "Institute in

\footnotetext{
As Adam Liptak argued in The New York Times in 2008, "citations to foreign and international law in recent Supreme Court decisions ignited an enormous furor in Congress and in the popular consciousness." 'US Court is now guiding fewer nations' http://www.nytimes.com/2008/09/18/us/18legal. html?hp=\&adxnnlx=1221750684x/TQo9BGKg/1OAw\%20yvju8A\&pagewanted=print, on 19 December 2013.
} 
the Teaching of International and Comparative Law". In his trailblazing 1950 article "Comparative and Foreign Law in American Schools," describes in detail the Institute's meeting. The article includes an appendix with a list showing that by then twenty six law schools already offered courses in general comparative law. When thirty years later Stewart Schwab - the present Dean of Cornell Law School - took a teaching position at Cornell, he noticed that the law school's curriculum included some eight classes with comparative themes, typically European community law. In 2013 - more or less sixty years after Stevenson's research - Dean Schwab reported that the number of comparative courses at Cornell had more than trebled: out of 150 classes offered some 30 had comparative themes, comprising roughly $20 \%$ of the Law School's curriculum. ${ }^{11}$

What about comparative constitutional law? Perhaps on account of some temperamental insularity inherited from the British, which generated what Ackerman has labeled "constitutional provincialism," 12 the idea of comparative analysis took more time to fly in the American constitutional domain. But in recent times the new comparative wave has also washed the constitutional shores - both the academic and the judicial ones. The transformation has been so significant that it would be quite fair to acknowledge that regarding comparative constitutional law the US is today the main experimental lab in the whole world: where the pros and cons of the comparative venture as applied to the constitutional field are more deeply explored; where the main questions - the very questions that are similarly relevant for the same comparative inquiry elsewhere - are examined and dissected.

I will now display two important indicators showing that comparative constitutional law as an academic discipline is booming in North America. First, the significant number of law schools that offer not just comparative courses but more specifically comparative constitutional law courses, under several names (though for the most part they are just called that: "Comparative Constitutional Law"). A non-exhaustive list speaks of some 36 schools, including the likes of

10 Stevenson JR, 50 Columbia Law Review, (1950) 613, 623-628

11 Schwab SJ, speech at the Third Annual Meeting of the Law Schools Global League, a Conference on Globalisation of Legal Education and Legal Profession, Jindal Global Law School, Sonipat, India, 27-28 February 2013. Personal notes on file with the author.

12 Ackerman B, 'The rise of world constitutionalism' 83 Virginia Law Review (1997) 771, 773-774. See also Harding SK, 'Comparative reasoning and judicial review' 28 Yale Journal of International Law (2003) 409, 417-423 for a good account of what she calls constitutional “isolationism”. Ackerman's own expression is a close cousin to "exceptionalism". In the words of Eric Posner, "American exceptionalism [is the] view going back 200 years [...] that we've figured it out and people should follow our lead." Interview quoted by Liptak, New York Times (2008) above. 
Yale, Harvard, Columbia, Chicago, New York University (NYU), Penn, Cornell, Georgetown, Notre Dame, Boston University, Boston College, American University, Fordham and Virginia. ${ }^{13}$ Yale offered at one time as many as four different courses on topics akin to comparative constitutional analysis. ${ }^{14}$ Furthermore, some law schools that offer their students a summer program of studies abroad typically include "Comparative Constitutional Law" in their program's curriculum. ${ }^{15}$ Finally, the rise of the discipline is also reflected in the activities of the above mentioned Association of American Law Schools, whose 2008 mid-year meeting featured in the limelight "alternative constitutionalisms" - including "comparative constitutional law". ${ }^{16}$

Secondly, it is striking how many quality books on comparative constitutional law have been published in the US in the last few years. ${ }^{17}$ Top scholars such as Mauro Cappeletti, Norman Dorsen, Karl Loewenstein, Walter Murphy, Giovanni Sartori, Vicki Jackson, and Mark Tushnet - all of them from the US or based therein - have written one or more volumes on the topic. Another nonexhaustive list, this time of books and treatises published in the US exclusively devoted to the discipline, includes twenty, most of which appeared early in the third millennium. ${ }^{18}$ On top of this, one ought to count as well the huge number of law review articles devoted to comparative constitutional analysis. ${ }^{19}$ Finally, one ought to count too the fact that in 2003 a group of renowned scholars

13 By way of confirmation of the trend illustrated supra, it is worth noting what the president of the AALS signaled in her annual 2001 message: "in an AALS Curriculum Survey done a short time ago, it was found that the single largest growth areas by far in law school curricula in the last five years has been in the international and comparative law fields." http://www.aals.org/presidentsmessages/ pmnov01.html, on 7 January 2014.

14 The relevant courses offered by Yale Law School in 2013 were Comparative Constitutional Law, Comparative Administrative Law, Comparative History of Human Rights and European Convention on Human Rights: Selected Problems. See http://www.yale.edu/printer/bulletin/htmlfiles/ law/course-offerings.html, on 8 January 2014.

15 Two such examples, with which I'm familiar, given that their summer programs take place in my country, Argentina, are Louisiana State University's Law Center and Valparaiso University Law School but there are many more.

16 See http://www.aals.org/events_2008constitutionalwhy.php, on 8 January 2014.

17 It has been recently pointed out that "once a relatively obscure and exotic subject studied by the devoted few, comparative constitutionalism has become one of the more fashionable subjects in contemporary legal scholarship." Hirschl R, 'Editorial' 11 International Journal on Constitutional Law 1 (2013) 1, 2.

18 Those most in vogue are Jackson VC and Tushnet M, Comparative constitutional law, Edward Elgar Publishing, (2006) and Dorsen N, Rosenfeld M, Sajó A, Baer S, Comparative constitutionalism, (2010).

19 Those articles include, among many others, one directly on point by a current Supreme Court Justice. See Ginsburg RB, 'Looking beyond our borders: The value of a comparative perspective in constitutional adjudication' 22 Yale Law and Policy Review (2004) 329. See also Breyer S, ‘Constitutionalism, privatization and globalization: Changing relationships among European constitutional courts' 21 Cardozo Law Review (2005) 1045. 
founded the International Journal of Constitutional Law $(\cdot \mathrm{CON})$. It is published by Oxford University Press in association with NYU and it is, to a large extent, dedicated to comparative constitutional law.

\section{Judicial Comparative Constitutional Law}

It is a truth widely acknowledged that US courts have traditionally ignored the jurisprudence of foreign courts in constitutional matters. ${ }^{20}$ This has changed in recent times, when the debate on the use of foreign law in those matters gained currency in the Supreme Court, partly in light - and, presumably, partly as a consequence - of the academic developments accounted for in the preceding section. Not only have Supreme Justices actually debated in public on the topic (and written about it too), ${ }^{21}$ but also since the new millennium several Supreme Court cases have dealt point-blank with what I have called here judicial comparative constitutional law. Even before those cases were decided, however, there had been some concurring and dissenting opinions examining deliberately and reflexively the possibility of the use of foreign materials in constitutional adjudication. It is, for instance, commonplace to refer to the 1958 plurality opinion in Trop v. Dulles' allusion to the practice of "the civilized nations of the world,"22 later quoted with recognition of its authority by the majority of the Supreme Court in two of the key third millennium cases. ${ }^{23}$ Much later, it is worth recalling the dissents by Justice Breyer in Printz v. United States ${ }^{24}$ (1997) and in the denial of certiorari in Knight v. Florida $a^{25}$ (1999), coupled with the famous critical rebukes by Justices Scalia and Thomas, respectively. ${ }^{26}$

Notwithstanding these forerunners, the real action exploded in three more recent cases, two on capital punishment - Atkins v. Virginia ${ }^{27}$ and Roper v. Sim-

20 Calabresi and Zimdahl try to controvert the view that United States' courts have traditionally ignored the jurisprudence of foreign courts in constitutional matters, but in the end they recognise that the way the debate has been framed in recent times is novel. Calabresi SG and Zimdahl SD, "The Supreme Court and foreign sources of law: Two hundred years of practice and the juvenile death penalty decision' 47 William and Mary Law Review (2005) 743, 755.

21 See Ginsburg, 'Looking beyond our borders'; Breyer, 'Constitutionalism, privatization and globalization'.

22 Trop v Dulles, 356 US 86, 102 (1958) (Warren, CJ for plurality).

23 Atkins v Virginia, 536 US 304, 311 (2002) and Roper v. Simmons, 543 US 551, 561, 575 (2005).

24521 US 898, 976 (1997), Justice Breyer dissenting.

25528 US 990, 993 (1999), Justice Breyer dissenting in the denial of certiorari.

26 Printr, 521 US at 921, n.11 (Scalia, J.) and Knight, 528 US at 990 (Thomas, J.).

27536 US 304 (2002). 
mons $-{ }^{28}$ and a third one on the criminalisation of sodomy - Lawrence $v$. Texas. ${ }^{29}$ Given that the relevant lines in the latter case are substantially included in the former two I will focus on those, without prejudice to pertinent references to Lawrence (and other cases) when appropriate. Albeit briefly I will also address the even more recent case Graham v. Florida, ${ }^{30}$ where some of the newer justices joined the battlefield if only by substantially adhering to what had already been established by their colleagues in the forerunning cases. I should make clear from the outset that my aim is neither to reinvent the wheel nor to make complete and conclusive argumentative claims about the US Supreme Court's use of foreign law: there is a vast literature discussing the merits of the majority and minority positions within the Court in these three cases and it is not my intention here to be redundant. On the contrary, my survey is limited to what is strictly necessary for the development of the theory that I will sketch in the following sections.

In 2002, the Supreme Court overruled its 1989 decision in Penry v. Linaugh ${ }^{31}$ where a slim majority had ruled that the execution of the mentally retarded did not violate the Eighth Amendment's ban on cruel and unusual punishments. ${ }^{32}$ In Atkins v. Virginia ${ }^{33}$ the Court decided the opposite, by a 6-3 vote, considering that the "standards of decency that mark the progress of a maturing society" had evolved since Penry. ${ }^{34}$ After noting that the practice of the States regarding capital punishment in these situations "has become truly unusual, and it is fair to say that a national [legislative] consensus has developed against it," 35 the majority added some remarkable language in its landmark footnote 21 :

28543 US 551 (2005).

29539 US 558 (2003). The same year Lawrence was decided two cases on affirmative action touched the topic at stake in this article, though only by passing and in a less significant fashion. See Grutter v. Bollinger 539 US 306, 330 (majority opinion) and 344 (Ginsburg, J, joined by Breyer, J, concurring) and Gratz v. Bollinger, 539 US 244, 298-305 (2003) (Ginsburg, J, joined in part by Souter, J., concurring).

30560 US 48 (2010).

31492 US 302 (1989), per O'Connor, J. The majority regarding this part of the opinion also included Rehnquist, CJ, and White, Scalia and Kennedy, JJ.

32 "Mentally retarded" but capable of committing a crime according to the determination of a jury. See Penry, 492 US at 330-333 (majority opinion).

33 Atkins v Virginia, 536 US 304 (2002), per Stevens, J. (overruling Penry v Linaugh, 492 US 302 (1989)). The majority regarding this part of the opinion also included O'Connor, Kennedy, Souter, Ginsburg and Breyer, JJ. In their dissenting opinion Chief Justice Renhquist, and Justices Scalia and Thomas expressed the view that Penry ought to be upheld. As it is quite apparent, in 2002 two Justices changed their mind from 1989: O'Connor and Kennedy, who were in the majority of Penry and are also in the majority of the overruling case Atkins.

34 Atkins, 536 US, 312.

35 Atkins, 316. 
Additional evidence makes it clear that this legislative judgment reflects a much broader social and professional consensus. $[\ldots]^{36}$ Moreover, within the world community, the imposition of the death penalty for crimes committed by mentally retarded offenders is overwhelmingly disapproved. ${ }^{37}$

The Court went on to say that these factors, which include the prevailing practice in the world community, are "by no means dispositive;" and that they were only resorted to because "their consistency with the legislative evidence lends further support to our conclusion that there is a consensus among those who have addressed the issue." ${ }^{38}$ Nevertheless, this clear reference to foreign law and practice, though confined to a relatively short footnote, elicited an enraged reply from the dissenting Justices.

For Chief Justice Rehnquist, the resort to foreign sources with a view to determining the constitutional question at stake is not supported by precedent. Moreover, the Chief Justice (joined by Justices Scalia and Thomas) objected that he failed to see "how the views of other countries regarding the punishment of their citizens provide any support for the Court's ultimate determination." 39 In his separate dissent, joined by the other two, Justice Scalia went further: the practices of the "world community" are not only irrelevant but their "notions of justice are (thankfully) not always those of our people". ${ }^{40}$

36 In the part omitted in the text the Court notices that "several organizations with germane expertise have adopted official positions opposing the imposition of the death penalty upon a mentally retarded offender" and provides a few examples such as some medical associations and religious communities. Atkins at 316, n 21.

37 Atkins at 316, $\mathrm{n} 21$. In support of the view that the world community disapproves capital punishment for the mentally ill the court notices next, always within note 21, a brief for European Union as amicus curiae. Likewise, a year later, in Lawrence v Texas 539 US 558, 576 (2003), the Court looked again at Europe: the majority there invoked decisions of the European Court on Human Rights in search of "values we share with a wider civilisation" to support its own view regarding the prohibition of sodomy. Atkins, 536 US at 316, n.21.

39 Atkins at 324. In Lawrence the dissent opined in a similar vein that "the Court's discussion of these foreign views (ignoring, of course, the many countries that have retained criminal prohibitions on sodomy) is therefore meaningless dicta." Lawrence, 539 US at 598 (Scalia J, joined by Rehnquist CJ and Thomas, J).

40 Atkins, 536 US at 348. In Lawrence Justice Scalia, citing Justice Thomas in Foster, added on top of this that these are "dangerous dicta, however, since "this Court [...] should not impose foreign moods, fads, or fashions on Americans." Lawrence, at 598, citing Foster v Florida, 537 US 990, n (2002) (Thomas J, concurring in denial of certiorari). A few years later, Justice Scalia insisted ironically in replying to a dissent by Justice Stevens': "No determination of what rights the Constitution of the United States covers would be complete, of course, without a survey of what other countries do." McDonald v Chicago, 561 US (2010) (slip opinion at 10). See also the plurality opinion in this case on what Justice Scalia calls the "follow-the-foreign-crowd requirement". McDonald, plurality opinion, (slip opinion at 34-35, and nn. 28-29). 
Note 21 of the majority opinion in Atkins, coupled with the replies by the dissenters, became the first round of what was to become the modern fight around judicial comparative constitutional law. We will now consider the next episode of the saga, again in the context of capital punishment.

In Stanford $v$. Kentuckey ${ }^{41}$ the Supreme Court had held, in a vein similar to Penry $v$. Linaugh, and in the same year (1989), that the imposition of capital punishment on a juvenile delinquent did not constitute cruel and unusual punishment under the Eighth Amendment. As with Penry, the Court overruled Stanford: in 2005 a new majority - quite similar to the one in Atkins v. Virginia, and similarly slim $-{ }^{42}$ reasoned in Roper $v$. Simmons ${ }^{43}$ that the practice of the states had evolved since 1989 - again, along similar lines to the reasoning of the majority in Atkins.

According to Justice Kennedy's lead vote, by 2005 there were “objective indicia of consensus, as expressed in particular by the enactments of legislatures that have addressed the question."44 Furthermore, the majority of the Court's own independent judgment, which was also brought to bear on the matter, was too that "the death penalty is a disproportionate punishment for juveniles." 45 In this context of the judgment of the reasonableness of the death penalty as applied to juveniles, the Court navigates again the waters of judicial comparative constitutional law. But what in Atkins had been confined to a footnote, occupies a whole section of the majority opinion in Roper. ${ }^{46}$

In section IV of its opinion in Roper the Court attempts to explain its resorting to foreign authorities in this area of the law. First, to do so is "instructive" although "[t] his reality does not become controlling, for the task of interpreting the Eighth Amendment remains our responsibility." 47 Second, it is proper to acknowledge "the overwhelming weight of international opinion against the juvenile death penalty" 48 for while the former does not control the case's outcome, it "does provide respected and significant confirmation for our own conclusions." 49

41492 US 361 (1989), per Scalia, J. The relevant majority in Stanford is the same as in Penry: Rehnquist, CJ and White, O’Connor, Scalia and Kennedy, JJ.

42 The majority vote was signed by Justices Stevens, Kennedy, Souter, Ginsburg and Breyer. It is noteworthy that Justice Kennedy had been in the majority of Stanford, the case overruled by Roper, a decision where, furthermore, he is the author of the opinion of the Court.

43543 US 551 (2005).

44 Roper, 543 US at 552. See also Roper 567 and 574.

45 Roper at 564.

46 Roper section IV, the last one.

47 Roper at 575.

48 Roper at 578.

49 Roper at 578, emphasis added. 
Third, "the express affirmation of certain fundamental rights by other nations and peoples simply underscores the centrality of those same rights within our own heritage of freedom. ${ }^{" 50}$

In reply, a furious dissent by Justice Scalia ${ }^{51} 51$ denies this purported justification and challenges the seriousness of the majority's reasoning. According to the dissent, what the Court has really done, while denying doing so, is granting foreign law controlling authority in the Roper case. The basic premise of the majority's opinion would have really been that the laws of the US should conform to the laws of the rest of the world. ${ }^{52}$ Next, Justice Scalia critically targets the Court's allegedly selective use of foreign law: while it resorts to it here in Roper it ignores it in other areas of the law - he offers abortion as an example - where, perhaps, the outcome favoured by foreign law would be less congenial with the Court's views. ${ }^{53}$ But " $[t]$ o invoke alien law when it agrees with one's own thinking, and ignore it otherwise, is not reasoned decision-making, but sophistry." ${ }^{54}$

In 2010 the Court revisited our topic in Graham v. Florida. ${ }^{55}$ This time the question at stake was a related one, always within the neighbourhood of the Eight Amendment: whether juvenile offenders can be sentenced to life imprisonment without parole for nonhomicide crimes. In line with Roper, which, as we know, had excluded the death penalty for such offenders, in Grabam a similarly divided Court held that the imposition of capital punishment in those cases constituted cruel and unusual punishment. Justice Kennedy wrote again the majority opinion, which was also signed by the three other Justices whom, having signed Roper five years earlier, remained in the Court in 2010: Stevens, Breyer, and Ginsburg. ${ }^{56}$

$50 \quad$ Roper at 578.

51 Roper at 607 Chief Justice Rehnquist and Justice Thomas joined Justice Scalia's dissent. Note that two months prior to the decision in Roper v Simmons Justice Scalia had debated with Justice Breyer on the use of foreign law by the Supreme Court, as recalled in the Introduction, supra. Justice Scalia's views in Roper are certainly coherent with the ones expressed earlier at the debate. In fact the latter may serve as an interpretative tool to read the former. Justice O'Connor dissented separately. Roper at 587.

52 Roper at 624.

53 Roper at 625. Along the same lines now Chief Justice Roberts stated during his confirmation hearing that "looking at foreign law for support is like looking out over a crowd and picking out your friends." Liptak, 'US Court is now guiding fewer nations' note 7.

54 Roper, 543 US at 627.

55560 US 48 (2010).

56 In 2008 Justices Stevens, Breyer, and Ginsburg (together with Justice Souter, who was still in the Court) had also joined an opinion by Justice Kennedy on a related topic. In Kennedy v Louisiana, 554 US 407 (2008) a similarly divided Court held, along lines similar to those discussed in this section (but without resorting to comparative arguments) that capital punishment as applied to the rape of a child is unconstitutional under the Eight Amendment. 
Justice Sotomayor, who had replaced Justice Souter, volunteered the fifth vote and by so doing endorsed the substance of judicial comparative constitutional law as it had been expounded in Atkins, Roper, and Lawrence.

It is unnecessary to go deep into Graham here, given that there isn't much in the majority opinion that had not been present in the prior cases. ${ }^{57}$ Along the same lines of his opinion in Roper, and quoting it to remind us of the confirmatory role of comparative constitutional law, ${ }^{58}$ Justice Kennedy observes in the newer case that the sentencing practice considered unconstitutional is rejected the world over; and that this observation is supportive of the Court's conclusion though it does not control it. ${ }^{59}$ Interestingly, while quoting Atkins, Roper, and their forerunners to support the Court's resort to foreign sources in Graham, Justice Kennedy indicates that, at least in this area, judicial comparative constitutional law is a "longstanding practice." The opinion concludes with another reminder in the way of a quite solemn ratification of the non-controlling, confirmatory role:

The Court has treated the laws and practices of other nations and international agreements as relevant to the Eight Amendment not because those norms are binding or controlling but because the judgment of the world's nations that a particular sentencing practice is inconsistent with basic principles of decency demonstrates that the Court's rationale has respected reasoning to support it. ${ }^{60}$

The dissent, authored by Justice Thomas, is doubly interesting. On the one hand, it is the first time Justice Thomas writes an opinion about this, having in the past subscribed the dissenting views of Chief Justice Rehnquist (in Atkins) and of Justice Scalia (in Atkins and Roper). ${ }^{61}$

What he writes on our topic is skeptical, short and sharp, and deliberately confined to a footnote. For Justice Thomas the Court's discussion of foreign laws is but one chapter of its judicial fiat, given that "past opinions explain at

57 The Court applied to the issue at stake the test in Roper, i.e. whether there is a national consensus against the practice (section III, A of the majority opinion), and next exercised its own independent judgment about whether the punishment is cruel and unusual (section III, B). While concluding that it is cruel and unusual in exercise of its judgment, the Court ventured into judicial comparative constitutional law in a way pretty much identical to the one in section IV of the majority opinion in Roper (section III, D).

58 For instance 560 US 48 (2010) (slip opinion at 31).

59560 US 48 (2010) (slip opinion at 4). "The judgments of other nations and the international community are not dispositive as to the meaning of the Eighth Amendment."

60560 US 48 (2010) (slip opinion at 31).

${ }_{61}$ Justice Thomas had, however, penned a brief, but significant, concurrence in a denial of certiorari: Foster v Florida, 537 US 990, n (2002) (Thomas J concurring in denial of certiorari). 
length why such factors are irrelevant to the meaning of our Constitution." ${ }^{62}$ The reference to relevance is in stark contrast with the majority's view that "the climate of international opinion concerning the acceptability of a particular punishment' [is] 'not irrelevant".'. 33

On the other hand, given that Justice Alito joins Justice Thomas's dissent (as well as does Justice Scalia) we now know that Alito - another absentee in the first rounds of this battle - is with the dissenting team. It is also worth noting, by way of contrast, that Chief Justice Roberts - who also had not yet joined the Court when Roper and the other important cases had been decided- did not speak to the question of judicial comparative constitutional law in his opinion concurring in the judgment. ${ }^{64}$ Regardless of the merits of the judgments in these cases, the opinions in Atkins v. Virginia and, especially, Roper v. Simmons (and Grabam v. Florida), contain the seeds for a justificatory theory of judicial comparative constitutional law. I will therefore try next, in section 3, to condense such a theory in order to prepare the way for the crucial section 5 .

\section{Towards a Theory of the Use of Foreign Law in Constitutional Adjudication}

First, we must carve out the question at stake. The question is not whether a constitutional convention or an ordinary legislature may use foreign law when determining constitutional affairs and arrangements through enactments - what we could label legislative comparative constitutional law. Indeed hardly anyone objects to the legitimacy of that practice; and certainly some of the main participants in the debate examined in this paper do not object to it. Justice Scalia's dictum, writing for the majority in Printr. v. United States, is crystal clear: "We

62560 US 48 (2010) (slip opinion at n 11). Justice Thomas, dissenting, quoting Chief Justice's Rehnquist dissent in Atkins.

63560 US 48 (2010) (slip opinion at 29), quoting a footnote in Enmund v Florida 458 US 782, 796, n. 22 (1982).

64560 US 48 (2010) (slip opinion at 1). Justice Kagan, who joined the Court after Graham had been decided, expressed some of her views on comparative constitutional law during her confirmation hearings. "I'm in favor of good ideas [.. .] wherever you can get them." [...] "Having an awareness of what other Nations are doing [...] might be useful [...]." She also observed that on a point of US law foreign decisions do not rank as precedent, but they could be informative in much the same way as one might gain knowledge or insight from reading a law review article. The nomination of Elena Kagan to be an associate justice of the Supreme Court of the United States: Hearing on S. Hrg. 111-1044 Before the Committee on the Judiciary, US Senate (2010). 
think such comparative analysis inappropriate to the task of interpreting a constitution, though it was of course quite relevant to the task of writing one."65 Although this is likely a historical judgment referring to the US Constitution, it is reasonable to read some (positive) evaluation into the description. As one of Justice Scalia's long time companions in rejecting the use of judicial comparative constitutional law put it, "Congress, as a legislature, may wish to consider the actions of other nations on any issue it likes." 66

Legislative use of foreign constitutional legal materials is quite unproblematic because legislatures are free from the constraints that ordinarily bind judges; in the first place the constraint posed by the law itself, which can be the object of legislative, but not (usually) judicial, reform. Furthermore, even when legislative action is not per se reformative, legislating well requires the legislator to continually make discretional judgments that involve not only reasonableness but also efficacy and efficiency. In carrying out these judgments it is all but natural that the legislator would look abroad. For example if the legislator faces a given problem (x), and the same (or a similar) problem (x) has been faced and met successfully by the legislature of some neighbouring country it would be both intelligent and unobjectionable to look at their solution.

Jeremy Waldron offers the following analogical example:

Consider how we would expect our public health authorities to deal with a new disease or epidemic appearing within our borders. It would be ridiculous to say that because this problem had arisen in the United States, we should look only to American science to solve it. On the contrary, we would want to look abroad to see what scientific conclusions and strategies had emerged, had been tested, and had been mutually validated in the public health practices of other countries. ${ }^{67}$

Nevertheless, efficacy and successful tackling of problems are normally outside the typical scope of the judicial function. In the US this is also true in relation to constitutional rights adjudication, at least in principle, given the fairly traditional conception of the separation between legislative and adjudicative authority, a conception that still holds by and large. The same is true about other countries following the American constitutional model. ${ }^{68}$

65. Printr, 521 US at $921, \mathrm{n} 11$

66 Foster v Florida, 537 US 990, n (2002) (Thomas, J concurring in denial of certiorar).

${ }_{67}$ Waldron J, 'Foreign law and the modern ius gentium', 119 Harvard Law Review (2005) 129, 143.

68 A good example is the Constitution of Argentina (1853), basically modeled after the Constitution of US (1787). 
Waldron simplifies too much the question when he treats together legislative and judicial uses of foreign constitutional law as if there were a continuum. ${ }^{69}$ What happens at a pre-legislative (or pre-constitutional as the case may be) stage ought to be distinguished from the use of foreign constitutional law in adjudication - normally at a later stage, coming into place only once the relevant provision has been legislatively enacted. ${ }^{70}$ It is this isolated question the one we will focus on now, when we consider "whether comparative constitutional law is justified." ${ }^{71}$

The US Constitution, like most constitutions, ${ }^{72}$ is silent about this point. Yet I think that judges are morally justified to use foreign law in constitutional adjudication. While the ultimate reasons for this proposition will be developed in section 5 (below), I will explain here three caveats that must obtain for that use to be valid. As already anticipated, the seeds of this basic theory are already present in section IV of the majority opinion in Roper $v$. Simmons. ${ }^{73}$

Firstly, comparative constitutional law has a confirmatory role: comparative analysis is useful in order to ratify the reasonableness of a given national norm or practice. ${ }^{74}$ Of course this analysis (and its virtuality) depends on the existence

69 Waldron comments that "the idea of the law of nations makes itself available to law-makers and judges as an established body of legal insight [...]" also at 133, emphasis added. Similarly, Justice Breyer conflates legislation and adjudication in the following dictum: "Just as 'attention to the judgment of other nations' can help Congress determine 'the justice and propriety of [America's] measures', Madison J, The Federalist No. 63, C. Rossiter Edition, 196, 382 so it can help guide this Court when it decides whether a particular punishment violates the Eighth Amendment.” Foster v Florida, 537 US 990, 993 (Breyer, J, dissenting in denial of certiorari). For Justice Thomas' rebuke see supra text to note 53.

70 The exceptions to the timing described in the text are the a priori systems of judicial review. See Guarnieri C \& Pederzoli P, The power of judges, (2002) 143; and see generally Cappelletti M, The judicial process in comparative perspective (1989).

71 In this respect my interest is similar to Professor McCrudden's who stated in a seminal article: "I am mostly concerned in what follows with what happens after human rights legislation, or constitutional human rights provisions, have been introduced." McCrudden, 'A common law of human rights', 501 (2000).

72 Some constitutions expressly permit the citation of foreign law when interpreting the Bill of Rights. Article 39 (1) (c) Constitution of South Africa (1996).

73543 US 551 (2005). Others have already contributed with the clarification of constraints that ought to be added to the three mentioned in the text. For example, Amann rightly points out two criteria that already may be discerned in the Court's jurisprudence pre-Roper: "others must have considered the issue at hand in comparable circumstances; and those other decisions must derive from nations or systems that share with the United States a constitutive commitment to fundamental rights." Amann DM, Raise the flag and let it talk: On the use of external norms in constitutional decision making' 2 International Journal on Constitutional Law 4 (2004) 597, 598. Both criteria underscore "analogy", a key factor in the context - different but analogical - of common law reasoning. See Cross R and Harris JW, Precedent in English law (1991).

74 "The opinion of the world community, while not controlling our outcome, does provide respected and significant confirmation for our own conclusions." Roper, 543 US, 578, emphasis added. 
of such a national norm or practice and cannot substitute for it. For example, in Roper Justice O'Connor dissented not because she would not use foreign law in some constitutional cases ${ }^{75}$ but because in her view the mentioned prerequisite did not obtain in that particular case: "I do not believe that a genuine national consensus against the juvenile death penalty has yet developed [...] [Therefore] I can assign no such confirmatory role to the international consensus described by the Court." ${ }^{\text {76 }}$ Regardless of its concrete application to Roper the idea is good: the invocation of foreign law ought not to serve as an excuse to replace a valid norm or practice for the judge's own preferences; nor does it have the aptitude to transform in reasonable what is not. ${ }^{77}$ Judicial constitutional law ought not to become the law of rationalisation. In section 6 (below) I will provide one example of such rationalisation through the misapplication of comparative analysis.

Secondly, the use of foreign constitutional law has an educational role: comparative analysis is undertaken partly with a view to understanding and explaining better one's own legal system in a particular area of the law. When one learns a foreign language one typically learns more about one's own language; one realises that solutions that were thought to be given are actually mere possibilities. Likewise, relevant foreign constitutional law can illuminate the scope of one's own legal system. ${ }^{78}$ It can therefore be highly informative and instructive for the judge.

From the confirmatory and educational roles of comparative constitutional law follows, thirdly, that its use ought to be always obiter dictum: judicial constitutional reasoning may not rely solely on foreign sources that are not recognised by the constitution of the country as valid law. Those sources, while informative, do not control the outcome. ${ }^{79}$ This is not, however, to underestimate the role of comparative analysis. If the point is to reach sound constitutional legal conclusions (on questions especially where there is no settled constitutional answer),

75 Indeed, she would use foreign law sometimes: "I disagree with Justice Scalia's contention, post, 1522 (dissenting opinion), that foreign and international law have no place in our Eighth Amendment jurisprudence.” Roper, 543 US, 604.

76 Roper O'Connor, J, dissenting emphases in the original.

77 As Carozza states, "mere numerical consensus does not, per se, provide a sufficient foundation for making conclusive jugdments regarding the content of human rights norms". Carozza PG, "My friend is a stranger': The death penalty and the global ius commune of human rights" 81 Texas Law Review (2003)1031, 1078-1079. See also, Waldron J, 'Foreign law and the modern ius gentium', 139: "a consensus in either the law or the natural sciences can be wrong".

78 Someone who is quite skeptic on this score recognises, however, that "looking abroad may help us see our own constitutional scheme in a new light, and this, in turn, may lead to results that would not have occurred without resort to foreign materials". Rosenkrantz CF, 'Against borrowings and other non-authoritative uses of foreign law' 1 International Journal on Constitutional Law 2 (2003) 269, 288.

79 Roper, 543 US, 578. 
then the proper understanding of the foreign material will quite rightly feature decisively - even if not in a controlling fashion - in the line of argument leading to the conclusion that $(\mathrm{x})$ is the law.

The search for confirmation and instruction makes more sense in some areas of constitutional law than in others. For the reasons I will offer next the search is especially meaningful when it comes to the determination of the scope of fundamental human rights (and indeed it seems to be the case that as a matter of fact judges around the world have searched abroad more when it comes to those rights. ${ }^{80}$ Even though, as Posner points out, "the foreign court will not have been interpreting the same constitutional or statutory text or precedents that would frame and guide the analysis by the US court", ${ }^{81}$ it is true, nevertheless, that in some cases concerning fundamental rights the moral reasoning will be similar in every jurisdiction. For as Finnis puts it, providing a couple of examples, "[o]ur law against euthanasia and assisting suicide appropriately has virtually the same content as the natural moral law against such choices and actions, and debates about its positing (about enacting or retaining it) substantially track moral debate about the morality of those kinds of choice and act". ${ }^{82}$ Finnis's reference to natural moral law in this context anticipates my argument in the next section. For the time being it will suffice to underline that in cases such as those of his examples legal reasoning and moral reasoning overlap to a significant extent, turning less relevant the technicalities of each given legal system.

It is worth noting, however, that the implicit distinction between fundamental human rights questions from what we could term "structural" questions (e.g. those concerning federalism, separation of powers, and judicial review) is not always crystal clear. ${ }^{83}$ In the final analysis political and legal institutions structures- are there precisely to protect and foster fundamental human rights. This has been rightly noted in the United States: "The genius of the American Constitution lies in its use of structural devices to preserve individual liberty." ${ }^{84}$

80 Groppi and Ponthoreau, The use of foreign precedents, 416-417.

81 Richard Posner, No thanks, we already have our own laws, Legal Affairs, July/August 2004, at http://legalaffairs.org/issues/July-August-2004/feature_posner_julaug04.msp, on 26 January 2014.

82 Finnis J, 'Coexisting normative orders? Yes, but no' 57 American Journal of Jurisprudence. (2012) 111, 113.

83 Groppi, Ponthoreau, and their collaborators in an extensive field research noted as a matter of fact what I state normatively in the text: "A clear division between these matters [fundamental human rights and structural] has not always been possible [...].”. Groppi and Ponthoreau, The use of foreign precedents, 416.

84 Calabresi SG and Rhodes KH, 'The structural constitution: unitary executive, plural judiciary' 105 Harvard Law Review (1992)1153, 1155. In recent times the US Supreme Court has also noted this 
Perhaps this is why structural topics are also within the ballpark, especially in the field of academic comparative constitutional law, but sometimes too regarding its judicial version. ${ }^{85}$

Indeed the strong account of the universality of rights that I endorse in the next section, which includes the fundamental intelligibility of the common good, calls for such a potential extension at least in some contexts.

\section{Comparative Constitutionalism, Natural Law, and the Universality of Human Rights}

"[O]n this kind of an issue you're asking a buman question, and the Americans are human. [...] I thought our people in this country are not that much different than people [in] other places." ${ }^{86}$ Leaving aside the irony entailed by their predication of humanity, these words of Justice Breyer's in his debate with Justice Scalia provide a promising starting point for a sound discussion of the foundations of comparative constitutional law.

What kind of an issue is Justice Breyer talking about? He wants to contrast what he calls "a human question" with more "arcane" matters, such as those of "contract law, where a different legal system might have given the same words [a] totally different application." ${ }^{\text {" } 77}$ In the same vein, Justice O'Connor argued in Roper $v$. Simmons that while "American law is distinctive in many respects', the American 'understanding of human dignity certainly is neither wholly isolated from, nor inherently at odds with, the values prevailing in other countries. On the contrary, we should not be surprised to find congruence between domestic and international values $[\ldots]$. ." 88

The bottom line of Justice Breyer' and Justice O'Connor's assertions is that the search for confirmation and instruction in foreign law is particularly meaningful when it comes to the determination of the scope of fundamental human rights (although it is also meaningful regarding structural matters, for the reasons hinted in the last paragraph of section 4, above.) Indeed, with

connection between structure and rights with regard to one particular structural device: federalism: "Federalism secures the freedom of the individual". Bond v United States, 131 S. Ct. 2355, 2364 (2011).

85 Despite the prevalence of judicial comparative constitutional law in fundamental human rights matters, "citations are not completely absent in institutional decisions." Groppi and Ponthoreau, The use of foreign precedents, 417.

86 From the debate referenced supra, note 1, emphasis added.

${ }^{87} \quad I d$.

88 Roper, 543 US at 605, Justice O’Connor, dissenting. 
respect to those rights there is a certain convergence between the prevailing values of the different nations, regardless of whether they use or accept the term "human rights". As Finnis argued in 1980 in his Natural Law and Natural Rights, anthropological surveys entitle us to assert confidently that some goods, values and principles are virtually universal. ${ }^{89}$ This convergence cannot be just chance; ${ }^{90}$ and it should not pass unnoticed with a view to the assessment of the comparative enterprise, especially given that some of those goods have been encapsulated in modern times in the notion of human rights. Thus to predicate the universality of the former is to predicate the universality of those rights, or at least of their fundamental core.

This sociological universality of the core of human rights - a presupposition of comparative constitutional law, as I shall argue - is tied to a notion that is prior (though not in a chronological sense): natural law. ${ }^{91}$ As Carozza puts it "there are some implicit natural law premises operative in the phenomenon of cross-judicial discourse on buman rights (as distinct from other substantive areas of law)." ${ }^{92}$ Natural law too is purported to be universal in its basic core, though in a different, normative sense of universality. ${ }^{93}$ The famous words of Antigone about the unwritten laws of Hades apply mutatis mutandis to natural law: "their life is not of to-day or yesterday, but from all time, and no man knows when they were first put forth." 94

This is not the place for expounding a natural law theory. But it might be useful to borrow from one of its contemporary proponents, according to whom natural law is about the acceptance of "the objective value of human reason and the objectivity of what is good or evil regarding at least certain things that are

89 Finnis J, Natural law and natural rights, 2ed (2011) 83-84; 97.

90 Groppi and Ponthoreau hint in the right direction when they too signal toward a likely absence of chance: "[...] an explanation of frequent references to foreign precedents in this field is probably given by the universal character of human rights." Groppi and Ponthoreau, The use of foreign precedents, 416.

91 Though not without its own ambiguities, the term "objective critical morality" can substitute "natural law" in some contexts. As explained by Orrego, "natural" in "natural law" "does not mean something related to the physical world, but rather to the rational world of human morality. Hence the distinction between merely conventional morality and critical morality also captures the basic idea that some things may be morally good, and just, regardless of social conventions to the contrary." Orrego C, 'The relevance of the central natural law tradition for cross-cultural comparison: philosophical and systematic considerations' 8 The Journal of Comparative Law (2014), 32.

92 Carozza, My friend is a stranger', at 1082, emphasis in the original.

93 Finnis, Natural law and natural rights sections III-V.

94 Sophocles, The Antigone, Jebb R Transcript, 3ed, Cambridge University Press, 1990, 91 - emphasis added. 
basic human goods for all persons, regardless of time or culture" ${ }^{\prime 95}$ - thus making clear that, contrary to some commonplaces, the notion is not in itself about Catholicism, or Aristotelian accounts of nature, or inferring "ought" from "is."

If rightly understood natural law (under whatever name) is denied, and so is denied the normative universality of human rights (under whatever name), then judicial comparative constitutionalism is rendered unintelligible. (Though, to avoid overreaching, I must haste to note that that is only true for those who really deny natural law; some people think they deny it, while they actually accept its concept even without knowing they do so: more on this later. ${ }^{9}$ ) Posner, a staunch critic of the use of foreign law in constitutional adjudication and of natural law sees this clearly when he points out that to cite foreign law as authority "is to flirt with the discredited (I had thought) idea of a universal natural law." ${ }^{\prime 77}$ But discredit in itself should not control the issue at stake. Discredited ideas are sometimes valid ideas. More importantly, in the field of American constitutional law there is a version of natural law which has been, in my view, validly discredited as a constitutional theory. It has sometimes been called "natural law jurisprudence" and, as is well known, it has been traced to early decisions of the US Supreme Court that regularly relied on supposed natural law concepts (under different names!), sometimes to the expense of the written Constitution. ${ }^{98}$

When the theory revived, disguised as substantive due process jurisprudence, during the Lochner era, and later again with the Warren Court (and in some, more recent cases too), ${ }^{99}$ it triggered similar criticisms of resurrecting natural law. ${ }^{100}$ But this is not the natural law I have in mind in this paper when I suggest that natural law (under whatever name) is the best foundation for the rational possibility of comparative constitutionalism. Indeed, as Alford has remarked natural law jurisprudence qua constitutional theory is compatible with (and sometimes even adheres to) a version of relativism that denies moral truth. ${ }^{101}$ Nothing could be further from the view supported in this paper than this

\footnotetext{
95 Orrego, The relevance of the central natural law tradition', at 34.

96 See text to note 108 infra.

97 Posner, 'No thanks'.

98 Alford RP, 'In search of a theory for constitutional comparativism' 52 University of California, Los Angeles Law Review (2005) 639, 660-66 (citing Supreme Court decisions from the early years).

99 The concept of "implicit ordered liberty" has been cited numerous times in substantive due process jurisprudence of recent years. For example, from Griswold v Connecticut, 381 US 479, 500 (1961) onwards, see Alford, 'In search of a theory of constitutional comparativism', 667-673.

100 George RP, 'Natural law, the constitution, and the theory and practice of judicial review' 69 Fordham Law Review (2001) 2269, 2274-2275.

101 Alford RP, Roper $v$ Simmons and our constitution in international equipoise' 53 University of California,
} 
natural law jurisprudence. Not only does my classical conception of natural law commit to moral cognitivism but also it is compatible with (and indeed requires) the respect of the positivity of man-made, written laws. ${ }^{102}$ Furthermore, most times fundamental (natural) rights are incorporated into positive (most times international) law. But though these human rights laws and treaties are as a matter of fact human enactments their content remains "natural", i.e. moral, and therefore the question of the presence of natural moral law in comparative constitutionalism remains the same: one cannot do without it by means of merely arguing: "Ah, but these are positive laws!". So while it is true that big tranches of internationally protect ed human rights are apparently rooted in positive international law and do not rely on natural law - and therefore that judges rightly insist "on the constructed and (to some extent) contingent nature of decision-making on issues of contemporary human rights" 103 - this is all quite irrelevant to my argument here given that what matters really for our purposes is where those rights are ultimately rooted.

If one accepts that our common humanity underpins and makes sense of all that legal systems seek to achieve ${ }^{104}$ it is easy to see where the foundation of comparative constitutional law lies. As Carozza observes of the Supreme Court decisions on the topic "the normative force of the transnational jurisprudence we have examined is premised upon the recognition of the common humanity of all persons". ${ }^{105}$ This universality "consistently provides a justification for courts to take foreign sources into account [...]". ${ }^{106}$ When human needs and problems are similar, therefore, it seems reasonable to search for inspiration in the answers afforded by other human beings to those needs and problems.

Legal rules and institutions are not the mere expression of whim. ${ }^{107}$ Of course those who hold the contrary should not see any point in comparative constitutionalism, even if they sometimes indulge in it given that the comparative constitutionalist does not always need a full grounding in objective critical morality: for some comparative purposes more minimal, if no less robust, prop-

Los Angeles Law Review (2005) 1, 19.

102 See generally Legarre S, 'Derivation of positive from natural law revisited' 57 American Journal of Jurisprudence (2012 103-110 (discussing the different connections between natural and positive law).

103 McCrudden, 'A common law of human rights', 528 (2000). See infra n 108.

104 Finnis J, 'The priority of persons' in Oxford essays in jurisprudence: Fourth series 1-5, (2000), arguing that law is for the sake of persons, with citation of the Roman jurists.

105 Carozza, 'My friend is a stranger', 1080.

106 Id.

107 Waldron, Foreign law and the modern ius gentium', 145-146: "for those who see law as a matter of will, this sort of theory is at best just an opportunity for haphazard legitimation." 
ositions will do the job. Furthermore one can actually be grounded in the full set of natural law theory without knowing $i t !^{108}$ The distinction is analogous to the one between doing something well and doing something well with the knowledge that one is doing something well. Similarly, a person - a scholar, a judge - can be on the right track regarding the foundations of what he or she is doing - comparative constitutional law - with or without knowing that they are on the right track. Or: they can sometimes ignore or even deny natural law and, nevertheless, adhere to it unwittingly. What matters is not so much what they think or say they do but what they actually do: terms are less important than concepts and realities. So they can, perhaps, reject "natural law" doctrine, for whatever (good or bad) reason and, simultaneously commit to its import and premises. ${ }^{109}$

On the other hand, those who deny the reality of natural law (with or without denying the name; or even using it!) and hold to moral relativism should also feel no attraction to the comparative constitutional enterprise. ${ }^{110}$ For this enterprise presupposes that there is something good we all have in common: ultimately our humanity and its basic needs, that can be articulated in terms of rights (and political structures); it also presupposes that persons normally have the ability to know what that good is. In other words, the comparative enterprise presupposes some shared truth, accessible to human understanding, about what is at stake in constitutional governance. If one declares oneself, as the moral relativist does, an agnostic about such truth - about what is good, what is bad, what is better and what is worse - why bother to search for information about our neighbour's

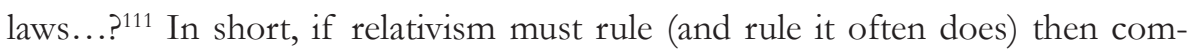
parative constitutional law is (or should be) superfluous and unintelligible. But if natural law (under any name or none) is accepted ${ }^{112}$ then the same enterprise

108 Compare McCrudden: "Another possible explanation is that judges consider [...] that human rights is some form of new natural law. This does not strike me as persuasive; certainly judges do not say that is what they are doing." McCrudden, 'A common law of human rights', 528, emphasis in the original (2000). It may be true that judges do not say they are accepting natural law as the foundation of comparative constitutional law; but that is not what really matters, as I argue in the text.

109 See text to note 95 infra.

110 As McCrudden puts it, "[f]or those who support cultural relativism, use of comparisons is pointless [...]”.McCrudden C, 'Judicial comparativism and human rights' in Örücü E and Nelken D (eds), Comparative law: A bandbook, Hart Publishing (2007) 373.

111 When the declaration of agnosticism entails intellectual corruption and blindness to reality, it is aptly captured by George Orwell's word "doublethink", as Finnis has reminded us in his recent writing. Finnis J, 'The priority of persons revisited' 58 American Journal on Jurisprudence 1 (2011) 45, 51.

112 It is worth noting that paramount critics of natural law such as HLA Hart and Joseph Raz have held the remarkable position that judges must adjudicate following at the same time the norms of the law and the norms of morality, and that both types of norms are to be coordinated in such a way that moral norms - in particular those that forbid the most serious injustices- must prevail over merely 
is reasonable and promising, provided one keeps in mind its limited role, as discussed in the previous section of this article. In the next section I will offer an example of what happens when the promise goes wrong in adjudication.

\section{The Misuse of Comparative Constitutional Law: An Example}

This section will attempt to show that, however promising, the comparative constitutional venture is not without risks. I shall do so by way of an example involving my own country, a case in which the US constitutional law on the "Establishment Clause" of the First Amendment ${ }^{113}$ has been improperly influencing the religious culture and practices of Argentina. The illustration shows an instance of a certain judicial use of foreign constitutional law that lies outside the boundaries described in this article.

Late in 2001, Argentina was undergoing a tremendous economic crisis. ${ }^{114}$ In order to cope with it the government froze most bank accounts. People went mad: some went wild while others were simply depressed. Some sued the banks and the government. They were sometimes sent by their lawyers to lobby judges by means of threatening that they would commit suicide if they did not get their money back instantly; others threatened the lives of the very judges who had to decide the cases; people from all walks gathered in the main hall of the so-called "Palace of Justice", home to the Supreme Court and to the most important federal courts: the crippled, the elderly, mothers with babies, persons who had not slept a wink for days, people under heavy medication. ${ }^{115}$ They all gathered in a form of protest. Of course, all this was immediately catalysed by the multiplying effect of television and the internet.

legal norms. See generally Orrego C, "Natural law under other names: De nominibus non est disputandum'” 52 American Journal on Jurisprudence (2007) 77-92.

113 US Constitution amend. I: "Congress shall make no law respecting an establishment of religion, or prohibiting the free exercise thereof $[\ldots]$ ".

114 See Spector H, 'Don't cry for me Argentina: Economic crises and the restructuring of financial property' XIV Fordham Journal of Corporate and Financial Law (2009) 771, 777-779. A similar crisis had already taken place in 1989. See Garcia-Mansilla MJ, 'Separation of powers crisis: The case of Argentina' 32 Georgia Journal of International and Comparative Law (2004) 307, 353-357. Indeed, García-Mansilla is right: "Economic emergencies are familiar in Argentina, as are restrictions on the economic rights of citizens during crisis." Id. at 354 .

115 This context was accurately described to me ten years after the events took place by one of the law clerks for the Federal Court of Appeals that in the end solved the case of the image of the Virgin Mary. Email of Juan José Galeano, 28 December 2011, on file with the author. 
A group of protesters decided to place an image of the Virgin Mary in the main hall of the "Palace of Justice". The Supreme Court itself acquiesced to the placement of the image, though it is not clear from the record how the authorisation effectively materialised. ${ }^{116}$

Hundreds assembled there every single day to pray that their deposits would be released. This offered some relief to many.

The Palace of Justice had become, too, a Temple of Justice. But some did not like this. They felt that their own constitutional rights were being affected by this transformation of the building. "Asociación por los Derechos Civiles" ("ADC"), a human rights NGO significantly funded by Ford Foundation, ${ }^{117}$ filed suit against the Supreme Court requesting the removal of the image of the Virgin Mary from the Palace of Justice. ${ }^{118}$ The ADC claim was premised in part on a purported analogy between the Constitution of Argentina and the Establishment Clause of the First Amendment to the US Constitution; and on American constitutional case law on religious freedom. ${ }^{119}$

ADC did not object to the constitutional right to religious freedom of the praying petitioners but contended that it was limited by the rights of others. According to ADC, the Supreme Court's authorisation of the presence of the image of the Virgin Mary and of collective recitation of prayers within the Palace of Justice jeopardised the right of everyone to be treated equally under the law. Non-religious people could reasonably get the impression that Catholics might be favoured by the courts. ${ }^{120}$ ADC distinguished the situation of the image of the Virgin Mary from the one in the American case Lynch v. Donnelly, ${ }^{121}$ where the US Supreme Court held that the public exhibition of a Christmas crèche by a municipality did not violate the First Amendment, given that it had a "secu-

116 According to Roberto Saba, then executive director of ADC - the claimant in the suit I am about to comment on - , the image of the Virgin Mary was placed, with the acquiescence of the Supreme Court, on 28 February 2002. Saba R, Laicidad y simbolos Religiosos 2 (2013).

117 See Asociación por los Derechos Civiles, La corte y los derechos 2005/2007 24 (2008) (statement by Roberto Saba and Álvaro Herrero in the "Foreword" to this official publication, acknowledging sustained contribution of the Ford Foundation). More information about ADC at http://www.adc. org.ar/sw_contenido.php?id=383, on 5 January 2012.

118 The suit was joined by two lawyers, Natalia Monti and Sebastián Schvartzman, invoking their own individual rights. Monti and Schvartzman were simultaneously on the legal staff of ADC. See http:// www.adc.org.ar/sw_contenido.php?id=383, on 5 January 2012.

119 Hernán Gullco, main counsel of ADC (and the attorney in charge of the law suit), kindly provided me with a copy of the claim. Email of Hernán Gullco, 27 December 2011, on file with the author. In Argentina there is a limited public access to legal documents produced by the parties.

120 Law suit, at section 3.1, on file with the author.

121 Lynch v Donnelly, 465 US 668 (1984). 
lar purpose" 122 independent of its religious origin. ${ }^{123}$ This kind of purpose was clearly absent, according to ADC, in the placement of the image in the Palace of Justice.

The district court agreed with ADC, relying in effect on the US case law, and treating it authoritatively as if it were a US district court. The Court consequently ordered the removal of the image. Several persons (invoking their affiliation to the Catholic religion) and "Corporación de Abogados Católicos" (an NGO that promotes Catholic values in the legal profession) appealed. When the Court of Appeals was considering the case, the image was removed as a consequence of an executive order of the Supreme Court intending to comply with the district court's judgment. Nevertheless, the Court of Appeals determined the case had not become moot and rendered a decision on the merits. ${ }^{124}$ One judge dissented, determining that the Supreme Court's acquiescence of the district court's ruling rendered unnecessary a judgment on the merits. ${ }^{125}$

The Court of Appeals disagreed with ADC's reasoning, which had been endorsed by the district court. A key tenet of the higher court's holding was that the Argentine system of religious freedom is different from "other systems such as, for example, that of the US". ${ }^{126}$

Therefore, the Court of Appeals held mistaken "the plaintiffs' invocation of foreign case law, rendered in the context of legal systems different from ours and hence inapplicable to this claim". ${ }^{27}$ The Court proceeded to explain what I have termed "the Argentine system of religious freedom" and argued that it is distinct or even unique. It awarded special relevance to Article 2 of the Constitution stating that " $[t]$ he Federal Government supports the Roman Catholic Apostolic Faith." 128

\footnotetext{
Id. at 679-680.

123 In section 3.2, the claim invokes another US Supreme Court decision, affording it apparent precedential value: West Virginia State Board of Education v Barnette, 319 US 624, 638 (1943). This is a serious mistake, as we shall see.

124 Cámara Nacional de Apelaciones en lo Contencioso Administrativo Federal, Sala IV [Cámara] [Federal Court of Appeals], 04/20/2004, "Asociación por los Derechos Civiles (ADC) y otros c/ EN (PJN)", Fallos de la Cámara [Fallos] (2004) (Arg.), at section 6.2 (available at http://www.pjn.gov.ar/ Publicaciones/00001/00015218.Pdf, on 11 January 2012).

$125 I d$., dissent of Judge Uslenghi, at section 5.

126 Id., vote of Judge Jeanneret de Pérez Cortés, who was joined by Judge Galli, at section 8.2.

${ }_{127} I d$., vote of Judge Jeanneret de Pérez Cortés, who was joined by Judge Galli, at section 9.1.

128 Argentine Constitution art. 2.
} 
Even though the Court of Appeals consequently overruled the district court's decision, the image of the Virgin Mary did not return to the Palace of Justice. ADC's claim and reasoning had been rejected but the Supreme Court did not issue a new authorisation for the placement of the image. Nevertheless, and given the rejection of its claim, ADC appealed. The Supreme Court reversed the Court of Appeals' decision in a 5-4 judgment without giving an opinion on the merits. Rather, in vacating the Court of Appeals' decision the majority of the Supreme Court held that a decision on the merits was unnecessary given that the image of the Virgin Mary was no longer in place at the time the Court of Appeals had decided the case. Four Justices dissented, reasoning that while a Supreme Court's decision on the merits had become unnecessary there was no need to overrule the Court of Appeals. Both the majority and the dissent agreed in that they would not pronounce a view of their own about the Court of Appeals reasoning, which remained uncontradicted.

After these summary remarks some observations are in order. While there is - as I have attempted to show above - value in a comparative approach to legal matters, not least in the area of constitutional law, it is one thing to recur to foreign materials as sources of illumination when interpreting one's own law but it is a different thing - as I have also anticipated - to substitute one's law for someone else's law affording the latter an authority it does not have in one's own legal system. This is what ADC would have had the Argentine judiciary do in the case of the image of the Virgin Mary - an instance of substitution under the guise of borrowing: substitution of what one does not like of a given legal system for what one prefers of another one; precisely what Justice Scalia has criticised in his denunciation of judicial comparative constitutional law. ${ }^{129}$

The case of the Virgin Mary is particularly enlightening. The kind of reasoning offered by ADC illustrates a mistake that ought to be avoided - a mistake swallowed by the district court but well-spotted by the Court of Appeals. Over-simple as it may seem, ADC's reasoning has the following steps: i) The US Supreme Court decided in Lynch v. Donnelly ${ }^{130}$ that the public exhibition of a Christmas crèche by a municipality did not violate the Establishment Clause of the First Amendment, given that it had a "secular purpose" independent of

\footnotetext{
129 According to Justice Scalia this selective use of foreign constitutional law is what happened (inter alia) in the Roper case. Roper, 543 US, 625 (Scalia, J dissenting). Paraphrasing Justice O'Connor, also in Roper, what the Court did in the Argentine case of the Virgin Mary was to assign US law a confirmatory role of an Argentine constitutional law that indeed does not exist. See Roper, 543 US O'Connor J dissenting, 604 and text to footnote 76 above.

130465 US 668 (1984).
} 
its religious origin; ii) The image of the Virgin Mary in the Argentine Palace of Justice does not have such secular purpose; iii) The exhibition of the latter image is in violation not only of the First Amendment of the US Constitution but also of article 2 of the Argentine Constitution.

Step (iii) of the above reasoning clearly is a non-sequitur. From the premise that the exhibition of the image of the Virgin Mary would be in violation of the First Amendment it does not follow that the display of the image would also be in violation of the Argentine Constitution. This should be quite obvious. US case law is not the law of the land in Argentina even when the Argentine Supreme Court often invokes decisions of its US counterpart. ${ }^{131}$ A precedent of the US Supreme Court, such as Lynch, ought not to be treated as in need of being distinguished as if it were otherwise binding for the Argentine Supreme Court.

Furthermore, the invocation of US precedents by the Argentine Supreme Court is normally circumscribed to areas of the law where the text and the history of the Constitution permit it. ${ }^{132}$

This is not the case with the area of religious freedom. Although the Argentine Constitution recognises a right to freedom of religion, ${ }^{133}$ a unique provision in Article 2 of the Constitution states that "[t]he Federal Government supports the Roman Catholic Apostolic Faith." This is in stark contrast with the Establishment Clause of the First Amendment to the US Constitution declaring that "Congress shall make no law respecting an establishment of religion." The difference is so evident that no more need be said on this score.

\section{Conclusion}

I have attempted to clarify the meanings and the boundaries of comparative constitutional law, having identified several realms where it is relevant. I have recognised separately what I termed academic and judicial comparative constitutional law, while acknowledging too the existence of legislative comparative con-

131 See Miller JM, 'The authority of a foreign talisman: a study of us constitutional practice as authority in nineteenth century Argentina and the Argentine elite's leap of faith' 46 American University Law Review. (2005) 1483, 1544-1553 (providing examples of the Argentine Supreme Court's borrowing of US precedents).

132 Julio C Rivera Jr., El uso del derecho comparado por parte de la Corte Suprema y la importación de la doctrina de la real malicia, 2011-IV J.A. 3, 8 (2011) (Arg.).

133 Article 14 Constitution of Argentina - "All inhabitants of the Nation enjoy the following rights, in accordance with the laws that regulate their exercise, namely: $[. .$.$] of freely practising their religion."$ 
stitutional law. These have different meanings and different boundaries. Judicial comparative constitutional law - the hardest case - is only justified if it remains within certain limits: for it to be a valid enterprise it ought to have a (merely) confirmative role; a pedagogic function; and an obiter dictum use.

Moreover, comparative constitutionalism (be it judicial, academic, or legislative), particularly (though not only) in the area of fundamental human rights, makes best intelligible sense if understood in the light of the classical notion of natural law (under whatever name) briefly discussed in this paper. The work of the legal philosopher comes here in the aid of the comparative constitutional scholar; and recent contributions have indeed been made to the discussion tackled in this article from the philosophical perspective of a revamped natural law theory. With solid foundations the comparative constitutional venture will more likely keep clear of defective uses and misapplications. 